\title{
The Populist Dream of Chinese Democracy
}

\section{ELIZABETH J. PERRY}

Mainstream Chinese discussions of "democracy" have long betrayed a decidedly populist understanding of the concept. Xi Jinping draws freely on this tradition in formulating his China Dream. Xi's efforts are part of the Chinese Communist Party's "re-Orientation" of official propaganda to showcase the glories of the ancient civilization that it claims to represent and rejuvenate. The idea of “democracy" (minzhu 民主)—understood in populist rather than institutional terms - plays an important role in the process. This populist interpretation of "democracy" seeks to elide the fundamental contradiction between Enlightenment values and illiberal politics. Whether it will prove persuasive to contemporary Chinese intellectuals remains to be seen.

\section{Prospects for China's Democratization}

CoOn after Mao Zedong's death in 1976, observers began to ask the seemingly obvious question: when will China democratize? In the early post-Mao period, heartened first by the Democracy Wall movement (1978-79) and then by the PRC's implementation of village elections and other political reforms, interest in the prospects for Chinese democracy grew apace (Fincher 1981; Nathan 1985; Schell 1988). Across the Taiwan Strait, Chiang Ching-kuo's lifting of martial law in 1987 encouraged expectations of top-down democratization on the mainland as well. Student protests in many Chinese cities in the late 1980s appeared at first to enjoy tacit support from a reform wing of the Chinese Communist Party (CCP), heightening hopes for political liberalization from above. Even the June Fourth massacre, followed as it was by the sudden collapse of communism across Eastern Europe and the Soviet Union, did not stifle predictions of democratization in China. Although the Chinese state was no longer seen as a likely source of top-down political reform, scholars sought the seeds of bottom-up political liberalization in the escalating popular protest, vibrant associational activity, commercialized media, and contentious Internet debate that marked post-Tiananmen society (Ding 2002; Gilley 2004; Goldman 2005; O’Brien and Li 2006; Ogden 2002; G. Yang 2009; Zhao 1998).

Today, however, nearly forty years after Mao's death and more than a quarter century after Tiananmen, the China field has largely retreated from predictions of imminent democratization in favor of resignation to authoritarian endurance (Heilmann and Perry 2011; Reilly 2012; K. Tsai 2007; L. Tsai 2007; Whyte 2010). The very factors that once were heralded as harbingers of political transformation-protests, NGOs, social media, a rising middle class - are now more often portrayed as operating within state-controlled constraints, thereby contributing to system stability rather than to

Elizabeth J. Perry (eperry@gov.harvard.edu) is Henry Rosovsky Professor of Government at Harvard University and Director of the Harvard-Yenching Institute. 
regime change (J. Chen and Dickson 2010; Chen Xi 2012; Wright 2010). Even the rare China scholar who prophesies the impending collapse of the Communist system does not paint a rosy democratic future. ${ }^{1}$ Moreover, Chinese leaders themselves appear more committed than ever to the perpetuation of CCP rule. Xi Jinping's recently announced "four comprehensives" (sige quanmian 四个全面) of governance-building a moderately prosperous society, deepening reform, governing the nation according to law, and being strict in governing the Party - repeat the familiar mantras of his autocratic forerunners. A "princeling" whose political power derives from his family connection to the founding generation of Chinese Communists, $\mathrm{Xi}$ has an obvious stake in maintaining and legitimizing the existing political system. Prospects for electoral democracy appear dim indeed.

Not only has China come to be viewed as a bastion of authoritarianism; increasingly it is seen as intent upon exporting its undemocratic practices in a calculated bid to displace the United States and its democratic way of life. A new book by Michael Pillsbury (2015) claims that China's actions are guided by a secret plan known as the "Hundred-Year Marathon," which seeks to restore China to its "proper" place atop the global hierarchy by establishing a new world order favorable to China. Chinese strategy, Pillsbury maintains, includes undermining the appeal of an American model of electoral democracy. A recent article in the Journal of Democracy by Larry Diamond $(2015,151)$ also warns that the Chinese are "pushing back against democratic norms" by trying "to discredit Western democracies and democracy in general, while promoting their own models and norms."

Observers are certainly correct to point to an emergent Chinese assertiveness, which is apparent in the PRC's muscular approach to everything from old maritime disputes (e.g., the Senkaku/Diaoyu Islands) to new multilateral institutions (e.g., the Shanghai Cooperation Organization and Asian Infrastructure Development Bank). But China’s growing confidence in performing on the world stage has not actually been accompanied by an attack on democratic norms or democracy in general, nor has it been buttressed by overt proselytizing of alternative authoritarian models and norms. As China specialist Andrew Nathan $(2015,158)$ notes in an article immediately following that of Diamond in the Journal of Democracy, "For now, at least, China displays no missionary impulse to promote authoritarianism." Although Nathan details half a dozen ways in which China’s policies exert a decidedly negative impact on the fate of democracy around the world, he acknowledges nevertheless that "Chinese propaganda does not explicitly characterize China's system as undemocratic, instead describing it as 'socialist democracy,' 'Chinese-style democracy,' and 'people’s democratic dictatorship' among other locutions" (161).

How should we interpret the Chinese state's frequent use of the term "democracy" (minzhu 民主) to characterize its own political system? Is this nothing more than a case of obfuscating rhetoric on the part of a disingenuous regime? Or is the label to be taken more seriously - if not as an accurate appellation for China's present political system, then perhaps as an authentic aspiration for the future? The Chinese Communist Party features democracy prominently on its list of priorities for national modernization. Whether or not China has a secret "Hundred-Year Marathon" plan to overtake the United States, as Pillsbury (2015) claims, it does have an openly declared hundred-year plan of democratization. In November 2012, the 18th Party Congress of the CCP (which

${ }^{1}$ Shambaugh (2015) foresees a collapse that is "likely to be protracted, messy and violent." 
selected Xi Jinping as its new general secretary) concluded with the promise, "within one hundred years after the founding of New China (i.e., by the year 2049), to build a socialist modernized country that is prosperous, democratic, civilized, and harmonious" (zai xin Zhongguo chengli 100nian shi jiancheng fuqiang minzhu wenming hexie de shehuizhuyi xiandaihua guojia 在新中国成立 100 年时建成富强民主文明和谐的社会主义现代化国家）(Xi 2014, emphasis added).

One year later, in December 2013, the official Party newspaper People's Daily ran a series of editorials introducing a set of one dozen so-called "core socialist values" (shehuizhuyi hexin jiazhiguan 社会主义核心价值观) that both the Party and the people are enjoined to cultivate and practice. Forming the main pillars of Xi Jinping's "China Dream," these values include the four national goals of prosperity, democracy, civility, and harmony (fuqiang minzhu wenming hexie 富强民主文明和谐); followed by four societal goals of freedom, equality, justice, and rule of law (ziyou pingdeng gongzheng $f a z h i$ 自由平等公正法治); and four individual values of patriotism, professionalism, integrity, and friendship (aiguo jingye chengxin youshan 爱国 敬业诚心友善) (Xinhua 2014a). Billboards across China advertise the "core socialist values," and newly edited textbooks at every educational level expound on their importance.

It is noteworthy that democracy (minzhu 民主) ranks second on the Party's list of twelve core values, trumped only by national prosperity (fuqiang 富强). It is even more striking that the CCP's paramount leader, Xi Jinping, insists that the cultivation and development of all twelve core values must be firmly based on "Chinese splendid traditional culture” (Zhonghua youxiu chuantong wenhua 中华优秀传统文化) (Xi 2014, 163-64). If the "democracy" that the Communist Party has in mind is rooted in Chinese tradition, then clearly it refers to something quite different from what American social scientists generally have in mind when we debate the prospects for China's democratization.

\section{China's Populist "Democracy"}

According to China's official news agency, Xinhua (2014b), the term "minzhu" connotes a broader and deeper meaning of democracy than is captured by any purely institutional or operational definition stressing competitive elections, majoritarian rule, or popular checks on central government power. The "minzhu" advocated by leading intellectuals throughout the course of Chinese history, Xinhua tells us, derives from the ancient political principle of "the primacy of the people" (yi min wei zhu 以民为主). This idea is traced back to the Book of History or Shujing 书经 with its pronouncement that "the people are the sole foundation of the state; when the foundation is firm the state is peaceful" (min wei bang ben, ben gu bang ning 民惟邦本, 本固邦宁), a notion that was further developed by Mencius in a famous passage: "the people are most important, the country comes next, the ruler is the least important" (min wei gui, sheji ci zhi, jun wei ging 民为贵, 社稷次之, 君为轻). ${ }^{2}$

In discussions of Xi Jinping's contemporary Mass Line Education and Practice Campaign, Communist Party theoreticians locate its intellectual pedigree within a Chinese

${ }^{2}$ The Shujing passage is from Book III. 
tradition of “populism” (minben sixiang 民本思想) that extends from Mencius through the Mass Line (qunzhong luxian 群众路线) of Mao Zedong and other early CCP revolutionaries (Liu Chuansheng and Wei Zhimin 2013a, 34-36; 2013b, 31). Much is made, for example, of an earthy injunction by Xi Jinping's own father, Xi Zhongxun, at a wartime cadres' conference on legal administrative reform: "Plant your asses squarely on the side of the masses" (ba pigu duanduandi zuo zai laobaixing de zheyimian 把屁股端端地 坐在老百姓的这一面) (Liang Yanhui 2013, 41-42). While Western social scientists are prone to conflate legal reform with political liberalization, in the Chinese context (imperial and Communist alike), legal reforms have more often been associated with populism than with liberalism (Liebman 2011).

In contrast to this indigenous populist tradition, contemporary CCP theorists counterpose Anglo-American democracy as deriving from a Western tradition of "humanism" (renben sixiang 人本思想) that stretches from the ancient Greek adage, "Man is the Measure of All Things," through the Renaissance to Enlightenment conceptions of natural rights. ${ }^{3}$ Interestingly, these party theoreticians do not deny or denigrate the value of Western democratic ideas and institutions. Rather, they acknowledge that certain prominent features of their own political system, most notably People's Congresses, have no antecedents in Chinese tradition and were obviously inspired by the example of Western legislatures, as interpreted by the Soviet Union (Zhang 2013; see also Leib and He 2006). Moreover, they argue that China still has much to learn from Western democratic theory and practice. For example, some authors point to Australian political theorist John Dryzek's writings on deliberative democracy (xieshang minzhu 协商民主) as a particularly useful source of ideas for improving Party-mass relations. Deliberative democracy, in which ordinary citizens are invited to participate in discussions about government policies, they suggest, may be better able than electoral democracy to encourage compromise among conflicting interests, an essential attribute of any functional system of governance in today's increasingly complex and diverse world (Liu Chuansheng and Wei Zhimin 2013a, 162-64; see also Leib and He 2006).

The writings of CCP theoreticians are not necessarily reflective of popular attitudes, of course. And among Chinese citizens, as among Americans, understandings of democracy vary widely. But an institutional definition of democracy that requires the selection of political leaders via competitive elections with universal suffrage does not seem to be what most Chinese have in mind when they speak of "minzhu." An encounter between an American reporter and a Chinese student in Tiananmen Square at the height of the "Democracy Movement" in the spring of 1989, recorded by eyewitness Craig Calhoun, is telling. Calhoun, a prominent sociologist who was teaching at a university in Beijing at the time, recalls,

Around May 18, several of my Chinese students and I were marching along Chang'an Boulevard on our way into Tiananmen Square. A reporter for a California newspaper strode alongside us and asked me to tell her what the students really wanted. "Ask them yourself," I said, "they speak English.” She asked one,

${ }^{3}$ Of course, they might also have noted that the English term "democracy" derives from the Greek "demos-kratos" or "people-power," and that Athenian democracy was predicated on the desirability of direct citizen participation in governance (Ober 2007). 
who replied simply, "Democracy." "What do you think democracy means?" she asked, as though of a child. My student responded with exaggerated humility, "Oh! You come from America. What does democracy really mean to you?" The reporter stammered, "Well, er, um, you know, elections I guess." "Ah," said the student, "I think more in terms of Rousseau and the model of direct participation.” (Calhoun 1997, 243-44)

While this particular student was surely more articulate on the subject of democracy than many Chinese citizens (not to mention American journalists), her answer does nevertheless indicate a more populist conception of democracy than a Schumpeterian stress on competitive elections would imply. In this populist view, the goal is not to restrain government, but to empower it through the active political participation of the citizenry. The student's reference to Jean-Jacques Rousseau in this regard is apt-evoking a radical understanding of democracy that infused not only the 1989 student movement, but also the Cultural Revolution that preceded it. Political theorist Benjamin Schwartz (1970, 158-60) noted shortly after the onset of the Cultural Revolution that the ideological underpinnings of Mao's tumultuous campaign bore more than a passing resemblance to Rousseau's doctrines of "civic morality" and "general will" as applied by Jacobins during the French Reign of Terror.

As Daniel Chirot emphasizes in his introductory essay, illiberal challenges to Enlightenment values have been a recurring feature of the modern era in Europe and the United States as well as in Asia. In contemporary China, political illiberalism has often taken the form of mass "revolutionary democracy." A retrospective on the 1989 Tiananmen Uprising by (now) Nobel laureate Liu Xiaobo offers a stinging critique of the mass protest he helped inspire, indicting it as an undemocratic movement that unwittingly reproduced many of the worst features of Chinese Communist revolutionary practice and culture:

Most of the resources and methods we made use of to mobilize the masses were ones that the Communist Party had used many times before.... As soon as we began our revolution, we became extremely conceited - just as if we had reverted to the time of the Cultural Revolution and felt ourselves to be the most revolutionary. As soon as we joined the 1989 protest movement, we considered ourselves to be the most democratic. After all, had we not fasted for democracy and devoted ourselves to it and made sacrifices for it? ... Our voice became the only truth. (Liu Xiaobo 1994, 315, 318)

The conflation of revolutionary mass participation and Communist Party leadership with "democracy" was certainly a hallmark of Maoism (Mao 1940). But the tendency to identify the will of the people with the strength of the nation has an older lineage, reflected in Chinese visions of democracy ever since Liang Qichao's seminal writings on the subject in the late nineteenth century. As Andrew Nathan $(1985,128)$ explains, "democracy was seen as a highly efficacious means of tapping the vast energies latent in the masses to propel the country out of backwardness and into a position of world power."

An analysis of Chinese political culture by a political scientist at the Chinese Academy of Social Sciences, based on a national survey of political attitudes conducted in 1988-one year before the Tiananmen Uprising-highlights this more expansive 
view of state-society relations. The author titled the work Chinese Political Man (Zhongguo zhengzhiren 中国政治人), in an obvious reference to Seymour Martin Lipset’s (1960) classic work on American politics, and used a four-character Chinese phrase, "Prevent Harm/Promote Good" (yi'e yangshan 抑恶扬善), to capture what he saw as a fundamental contrast between the political cultures of the two countries. Whereas Americans purportedly believe that the chief purpose of government is to prevent harm by restraining individuals and groups from pursuing their own interests at the expense of others, Chinese are said to envision a more proactive and populist mission for their government of promoting good-with officials expected to set forth goals for the betterment of society and to guide citizens in achieving those collective goals (Zhang 1994).

In China, populist conceptions of democracy, for which the litmus test of a "democratic" government is whether it benefits the people and reflects the will of the people, seem consistently to trump electoral conceptions. In a 2011 national survey of political attitudes conducted under the auspices of the Chinese Academy of Social Sciences, only a small minority of respondents ( 15 percent) agreed with the statement that "democracy means a system of periodic elections in which national leaders are chosen through competition between political parties." The overwhelming majority (85 percent) preferred a definition of democracy as "a system in which government leaders reflect people's interests, serve the people, and submit to supervision by the people." Responses varied by education, with better-educated respondents more likely than their less-educated counterparts to equate democracy with electoral competition. But even among the best educated, the vast majority (75 percent of those with $\mathrm{PhD}$ and $\mathrm{MA}$ degrees) chose the "populist" over the electoral definition of democracy (Zhang 2013, 57-60).

More interesting than the definitional issue were responses to questions about the desirability and feasibility of electoral democratization. One survey question read, "In America, there are two major political parties. Every few years there are regular election campaigns in which the two parties contend for government leadership positions. Do you think China now or in future should develop in this direction?" A clear majority, 61 percent, chose the "should not" option. Again, better-educated respondents were more sympathetic to American-style democracy than their less-educated counterparts, but still only 50 percent of PhD and MA degree holders expressed support for China moving in this direction (Zhang 2013, 81-84). When respondents were asked which three (out of five) factors posed the greatest obstacles to building democracy in China, "severe corruption" topped the list, with 72 percent of respondents selecting it; "leaders not fully committed to serving the people" was second with 52 percent; "severe bureaucratism" came in third with 48 percent; "inadequate mass supervision of government" ranked fourth with 46 percent; and "lack of regular competitive elections" came in a distant last, with a mere 19 percent of respondents choosing it as a major obstacle to China's democratization (91).

This general disinterest in electoral democracy may help to explain the notable lack of enthusiasm among mainland Chinese for Hong Kong's Occupy Central Movement last year (Yang Hengjun 2014). For many in the PRC, the real issue at stake in the protests was not the restrictive regulations for electing the Hong Kong chief executive. Popular discourse in the mainland denounced the Hong Kong demonstrators as unpatriotic ingrates whose actions betrayed both a lack of gratitude for China's generous assistance 
to the Island and a deplorable deficit of "Chinese cultural identity" (Zhonghua wenhua rentong 中华文化认同).

\section{The China Dream}

An emphasis on Chinese cultural identity is at the heart of Xi Jinping's China Dream, which envisions the rise of a powerful and wealthy nation and is presented as the Party's response to the collective yearning of the Chinese people. Shortly after his selection as general secretary of the Chinese Communist Party, Xi stood proudly in the Great Hall of the People in front of a monumental painting of the Great Wall where he referenced China's 5,000-year-old civilization and proclaimed that "realizing the great revival of the Chinese nation is the greatest dream of the Chinese people in modern history" (shixian Zhongghua minzu weida fuxing, jiushi Zhonghua minzu jindai yilai zui weida de mengxiang 实现中华民族伟大复兴，就是中华民族近代以来最伟大的梦想） (Global Times 2012; Xinhua 2013). Soon thereafter Xi led fellow members of the Politburo Standing Committee on a well-publicized visit to the National Museum of China to view an exhibition entitled The Road to Revival, which featured the heroic role of the Communist Party in spearheading China's nationalist struggles. Opening with China's humiliation in the mid-nineteenth-century Opium Wars, the exhibit concluded on a triumphal note with its declaration that "today the Chinese nation towers majestically in the Orient; the brilliant prospect of the great revival is already unfolding before us. The dream and quest of China's sons and daughters can definitely be realized!" (National Museum of China, n.d.). Employing a brand of extravagant rhetoric once reserved for praise of Chairman Mao's revolutionary line, the CCP was re-Orienting its propaganda to showcase the glories of the ancient civilization that it now claimed to be representing and reviving (Perry 2013).

In framing the national quest as a "dream," Xi Jinping draws upon imagery that has figured prominently in Chinese statecraft, philosophy, and literature for millennia. Oracle bone artifacts show that the interpretation of dreams in ancient China was often linked to critical military and political decisions by state rulers (Brennan 1993). The Daoist philosopher Zhuangzi is remembered for his vivid butterfly dream, which implied the possibility of radical transformation through active imagining and awakening (Watson 1996). ${ }^{4}$ The most famous novel in the Chinese literary canon is Dream of the Red Chamber; indeed, an entire field of academic research, known as "Redology" (Hongxue 红学), is devoted to its study.

Early twentieth-century Chinese intellectuals frequently chose to present their utopian visions of populist democracy in dreamlike style. In 1902, for example, Liang Qichao published a short novel entitled The Future of New China, which was set in the year 2062 in a prosperous land known as "Great Chinese Democracy" (Da Zhonghua minzhuguo 大中华民主国). ${ }^{5}$ The novel opens with the citizens of Great Chinese Democracy having invited a seventy-second-generation descendant of Confucius to deliver a lecture at the Shanghai World Expo on how Chinese democracy has been implemented in the country. The lecture of this latter-day Confucian draws a huge and appreciative

\footnotetext{
${ }^{4}$ On the theme of "awakening" in modern Chinese history, see Fitzgerald (1996).

${ }^{5}$ The Future of New China was originally published in Xin xiaoshuo 新小说 (New fiction) magazine.
} 
audience, including throngs of overseas visitors (Liang Qichao [1902] 2008). Literature scholar David Der-wei Wang (2015) observes that Liang Qichao's once futuristic novel exudes an "uncanny" aura of authenticity today, in the aftermath of the Shanghai World Expo and the establishment of hundreds of Confucius Institutes around the world. As Wang puts it, "the 'future' of new China seems to have become reality in the new millennium." The eerie sense of déjà vu anticipated in Liang Qichao's prescient novella notwithstanding, there are of course some key discrepancies between his vision and contemporary reality. Despite the Party's recent endorsement of Confucianism, the official ideology of the PRC remains Marxism-Leninism-Mao Zedong Thought.

Xi Jinping's China Dream draws eclectically upon imperial and revolutionary symbolism alike, as though part and parcel of one seamless and unitary "Chinese national tradition." But, essentialist and Orientalist as this construction may be, it is not put forward in opposition to Western democracy. Democracy, like science, is explicitly acknowledged by the CCP to be a key element of modern governance. However, the goal in embracing these twin Enlightenment values is not the flourishing of individual liberties but the flourishing of the Chinese nation. The term “Chinese nation," or Zhonghua minzu 中华民族, designates a kind of supra-nationality of Chinese people that both includes and transcends the Han majority nationality along with the fifty-five minority nationalities that together officially comprise the People's Republic of China (Elliott 2015, 187). This expansive ethnocultural construction is intended to appeal not only to a domestic constituency, but also to overseas Chinese who are expected to identify culturally and sympathize emotionally with the rise of the motherland. The growing pride and prosperity of the Chinese nation is seen as enhancing popular sovereignty, or "minzhu."

Massive anti-PRC protests in both Hong Kong and Taiwan last year suggest that not everyone in Greater China dreams the same dream, however. As the case of Taiwan in particular demonstrates, Chinese political culture is not uniform. Nor does Chinese culture pose an insuperable barrier to liberal democratization—even when "princelings" are in command. After all, Chiang Ching-kuo was also derided as a "princeling" when he first inherited the reins of power in Taiwan, yet he defied expectations by breaking with his father's autocratic practices.

It is hard to imagine Xi Jinping following in the footsteps of Chiang Ching-kuo, however. Xi's Anti-Corruption Campaign and Mass Line Education and Practice Campaign, with their hard-hitting attack on cadre corruption and harkening back to Mao's call to "serve the people" by adhering to the "mass line," are clearly intended to appeal to pervasive populist sentiments among PRC citizens. His approach is unlikely to promote change in a direction that most Americans would recognize as democratic, but - to the extent that Xi's efforts succeed in significantly reducing official corruption and bureaucratism, as well as strengthening the nation's global standing-his fellow compatriots may well credit him with advancing the CCP's century-long commitment to building minzhu.

\section{Conclusion: Intellectual Limits of the Populist Dream}

Will the Chinese Communist Party's populist dream succeed in finessing the fundamental contradiction between Enlightenment ideals and illiberal politics? Can the Party's 
syncretic blend of science, democracy, Confucian harmony, and Maoist revolution, all wrapped up in one dreamy package of national modernity, serve as a sustainable framework for regime legitimacy? Daniel Chirot notes that in the end it is up to intellectuals to take a stand on the ongoing battle between Enlightenment liberalism and the Counter-Enlightenment. How China's intellectuals will adjudicate this issue is far from certain.

Indeed, nowhere are the contradictions of the PRC's current intellectual climate more glaring than within the institution that most embodies the legacy of the Age of Enlightenment: the modern university. It is often assumed that great universities cannot thrive absent the freedoms of thought and expression that are guaranteed only under a liberal democratic polity. The PRC is betting otherwise. Spurred on by generous infusions of state funding, China's leading universities are embarked upon a concerted effort to enter the top ranks of "world-class universities." The ironies and ambiguities of this endeavor abound. While the Chinese state invests heavily in areas believed to be essential for building a twenty-first-century "knowledge-based economy" (i.e., the STEM fields of science, technology, engineering, and mathematics), it also appreciates that intellectual innovation may require exposure to the critical thinking found in the humanities and social sciences - despite serious worries about unwelcome liberalizing sideeffects of such exposure. As a result, universities in China offer Western-style liberal arts programs and Confucian-style learning alongside Party-mandated classes in political ideology and compulsory military training. Glitzy new mega-universities boast expensive infrastructure and handsomely funded “innovation bases” (chuangxin jidi 创新基地) equipped with state-of-the-art laboratories and other cutting-edge research facilities. At the same time, universities are firmly controlled by Communist Party committees, and Inspection Groups (xunzhizu 巡视组) reminiscent of Maoist work teams encourage students and faculty to lodge denunciations ( jubao 举报) against anyone suspected of political or ethical impropriety. On the one hand, China's Ministry of Education (MOE) urges its universities to "globalize" by engaging in a wide range of international academic programs and exchanges; on the other hand, the same MOE enjoins universities against adopting textbooks tainted by "Western values" (He 2015). Under the current regime, so-called New Left intellectuals (xinzuopai 新左派) enjoy far greater latitude for political expression than do China's beleaguered Liberals (ziyoupai 自由派).

Despite these contradictions and constraints, to date the party-state's approach to higher education appears surprisingly effective: Chinese universities have indeed been rising steadily in the global rankings of research universities (Kirby 2014). Moreover, amid a flood of popular protest that has engulfed nearly every sector of post-Tiananmen Chinese society, the country's college campuses have remained uncharacteristically quiet (Perry 2014).

Compliance of the Chinese intelligentsia is undoubtedly a condition of continued Communist Party rule. Yet, as every generation of student-led "democracy" movements from May Fourth to June Fourth dramatically demonstrated, such political quiescence cannot be taken for granted. Whether Xi's populist dream of recovering China's ancient glory will win the abiding allegiance of today's descendants of the New Culture Movement (or the "Chinese Enlightenment" as that heady period from the mid-1910s to 1920 s is often called) remains to be seen. After all, the most celebrated writer of 
the New Culture Movement, Lu Xun, warned darkly of the dangers of trying to modernize China on the basis of traditional values.

Lu Xun's scathing critique, Kuangren riji 狂人日记 (Diary of a madman; [1918] 1991), accused the Chinese tradition of having fostered a "man-eating society" that would have to be thoroughly expunged if the country were ever to advance toward a new and more humane future. ${ }^{6}$ Posthumously lionized by Mao Zedong in his On New Democracy (1940) as "the giant of China's cultural revolution," Lu Xun has always been revered as an iconic figure in the PRC. But these days Lu Xun's writings elicit less effusive praise from top Party leaders than in the past, due no doubt to his insistence on the fundamental incompatibility between "old” Confucian and "new” revolutionary ideas (Wasserstrom 2015).

In this day of the ubiquitous China Dream, it is worth recalling a remarkable statement that Lu Xun composed, not long before his death, on the subject of dreams:

\author{
Zuomeng, shi ziyou de, 做梦, 是自由的, \\ Shuomeng, jiu buziyou. 说梦, 就不自由. \\ Zuomeng, shi zuo zhenmeng de, 做梦, 是做真梦的, \\ Shuomeng, jiu nanmian shuohuang. 说梦, 就难免说谎. \\ To dream is to be free, \\ To talk about dreams is be unfree. \\ To dream is to dream real dreams, \\ To talk about dreams is surely to lie. (cited in Wang 2015)
}

The elegant verse of the most eloquent voice of the "Chinese Enlightenment" advises due skepticism toward the official articulation of dreams, implying the inherent limits of the Party's publicly proclaimed vision of populist democracy.

\title{
Acknowledgments
}

I thank the audience and fellow panelists at the Association for Asian Studies roundtable where this paper was first presented, as well as Teresa Wright and the editors of the Journal of Asian Studies for challenging questions and helpful suggestions. Harvard Fairbank Center Librarian Nancy Hearst provided expert research assistance.

\section{List of References}

Brennan, John. 1993. "Dreams, Divination, and Statecraft: The Politics of Dreams in Early Chinese History and Literature." In The Dream and the Text: Essays on Literature and Language, ed. Carol Schreier Rupprecht, 73-95. Albany: State University of New York Press.

Calhoun, Craig. 1997. Neither Gods nor Emperors: Students and the Struggle for Democracy in China. Berkeley: University of California Press.

${ }^{6}$ Kuangren riji was originally published in Xin qingnian 新青年 (New youth) magazine. For more on the "dark side" of Lu Xun, see Lee (1987). 
Chen, Jie, and Bruce J. Dickson. 2010. Allies of the State: China's Private Entrepreneurs and Democratic Change. Cambridge, Mass.: Harvard University Press.

Chen XI. 2012. Social Protest and Contentious Authoritarianism in China. New York: Cambridge University Press.

Diamond, Larry. 2015. "Facing Up to the Democratic Recession." Journal of Democracy 26(1):141-55.

Ding, Yijiang. 2002. Chinese Democracy after Tiananmen. New York: Columbia University Press.

Elliott, Mark. 2015. “The Case of the Missing Indigene: Debate Over a 'SecondGeneration’ Ethnic Policy.” China Journal 73:186-213.

Fincher, John H. 1981. Chinese Democracy: The Self-Government Movement in Local, Provincial, and National Politics, 1905-1914. New York: St. Martin's Press.

Fitzgerald, John. 1996. Awakening China: Politics, Culture, and Class in the Nationalist Revolution. Stanford, Calif.: Stanford University Press.

Gilley, Bruce. 2004. China's Democratic Future: How It Will Happen and Where It Will Lead. New York: Columbia University Press.

Global Times. 2012. "Xi Jinping Pledges "Great Renewal of Chinese Nation." November 30.

Goldman, Merle. 2005. From Comrade to Citizen: The Struggle for Political Rights in China. Cambridge, Mass.: Harvard University Press.

He, Laura. 2015. “China Probes College Textbooks for 'Western Values.” Market Watch, March 17.

Heilmann, Sebastian, and Elizabeth J. Perry, eds. 2011. Mao’s Invisible Hand: The Political Foundations of Adaptive Governance in China. Cambridge, Mass.: Harvard University Asia Center, distributed by Harvard University Press.

Kirby, William C. 2014. "The Chinese Century? The Challenges of Higher Education." Daedalus 143(2):145-56.

Lee, Leo Ou-Fan. 1987. Voices from the Iron House: A Study of Lu Xun. Bloomington: University of Indiana Press.

Leib, Ethan J., and Baogang He, eds. 2006. The Search for Deliberative Democracy in China. New York: Palgrave Macmillan.

LIANG QICHAO 梁启超. [1902] 2008. Xin Zhongguo weilai ji 新中国未来记 [The future of new China]. Guilin: Guangxi Normal University Press.

LiAng YANHUI 梁妍慧. 2013. Dang de qunzhong luxian jiaoyu shijian huodong anli 党的群众 路线教育实践活动案例 [Case studies from the party's mass line education and practice campaign]. Beijing: Central Party School Press.

Liebman, Benjamin L. 2011. "A Return to Populist Legality? Historical Legacies and Legal Reform.” In Mao's Invisible Hand: The Political Foundations of Adaptive Governance in China, eds. Sebastian Heilmann and Elizabeth J. Perry, 269-313. Cambridge, Mass.: Harvard University Asia Center, distributed by Harvard University Press.

Lipset, Seymour Martin. 1960. Political Man: The Social Bases of Politics. Garden City, N.Y.: Doubleday.

Liu Chuansheng 刘川生 and Wei Zhimin 卫志民. 2013a. Dang de qunzhong luxian 100wen 党的群众路线 100 问 [One hundred questions about the party’s mass line]. Beijing: People's Press.

. 2013b. Dang de qunzhong luxian jiaoyu huodong 党的群众路线教育实践活动 [The party's mass line education and practice campaign]. Beijing: Central Party School Press. 
LiU XIAOBo. 1994. "That Holy Word, 'Revolution.” In Popular Protest and Political Culture in Modern China, eds. Jeffrey N. Wasserstrom and Elizabeth J. Perry, 309-24. Boulder, Colo.: Westview Press.

LU XUN 鲁迅. [1918] 1991. Kuangren riji 狂人日记 [Diary of a madman]. Taipei: Linbai Press.

Mao Zedong. 1940. On New Democracy. In Selected Works of Mao Tse-tung, Marxists Internet Archive. https:/www.marxists.org/reference/archive/mao/selected-works/ volume-2/mswv2_26.htm (accessed July 31, 2015).

Nathan, Andrew J. 1985. Chinese Democracy. Berkeley: University of California Press. 2015. "China's Challenge." Journal of Democracy 26(1):156-70.

National Museum Of China. n.d. "The Road of Rejuvenation.” http://fuxing.chnmuseum. cn/intro.php (accessed April 18, 2013).

Ober, Josiah. 2007. “The Original Meaning of 'Democracy': Capacity to Do Things, not Majority Rule." Princeton/Stanford Working Papers in Classics.

O’brien, Kevin, and Lianjiang Li. 2006. Rightful Resistance in Rural China. New York: Cambridge University Press.

Ogden, Suzanne. 2002. Inklings of Democracy in China. Cambridge, Mass.: Harvard University Asia Center, distributed by Harvard University Press.

Perri, Elizabeth J. 2013. "Cultural Governance in Contemporary China: Re-Orienting Party Propaganda." Harvard-Yenching Institute Working Paper Series.

—. 2014. "Citizen Contention and Campus Calm: The Paradox of Chinese Civil Society." Current History (September):211-17.

Pillsbury, Michael. 2015. The Hundred-Year Marathon: China's Secret Strategy to Replace America as the Global Superpower. New York: Henry Holt and Co.

Reilly, James. 2012. Strong Society, Smart State: The Rise of Public Opinion in China's Japan Policy. New York: Columbia University Press.

Schell, Orville. 1988. Discos and Democracy: China in the Throes of Reform. New York: Pantheon.

Schwartz, Benjamin I. 1970. "The Reign of Virtue: Some Broad Perspectives on Leader and Party in the Cultural Revolution." In Party Leadership and Revolutionary Power in China, ed. John Wilson Lewis, 149-69. New York: Cambridge University Press.

Shambaugh, David. 2015. “The Coming Chinese Crackup.” Wall Street Journal, March 6.

Tsai, Kellee S. 2007. Capitalism without Democracy: The Private Sector in Contemporary China. Ithaca, N.Y.: Cornell University Press.

Tsai, Lily L. 2007. Accountability without Democracy: Solidary Groups and Public Goods Provision in Rural China. New York: Cambridge University Press.

Wang, David Der-Wei. 2015. "Panglossian Dream and Dark Consciousness: Modern Chinese Literature and Utopia." Unpublished paper.

Wasserstrom, Jefrrey. 2015. “A Century of Chinese Dreams and Chinese Nightmares, 1915-2015." Paper presented at Conference on China-Cuba: Trajectories of PostRevolutionary Governance, Tulane University, April.

Watson, Burton, trans. 1996. Chuang Tzu: Basic Writings. New York: Columbia University Press.

Whyte, Martin King. 2010. Myth of the Social Volcano: Perceptions of Inequality and Distributive Justice in Contemporary China. Stanford, Calif.: Stanford University Press.

Wright, Teresa. 2010. Accepting Authoritarianism: State-Society Relations in ReformEra China. Stanford, Calif.: Stanford University Press. 
XI JinPING 习近平. 2014. Tan zhiguo lizheng 谈治国理政 [The governance of China]. Beijing: Foreign Languages Press.

XINHUA NEWS. 2013. Minzu fuxing Zhongguomeng 民族复兴中国梦 [The China dream of national revival]. http://www.xinhuanet.com/politics/szxzt/zgm.htm (accessed July 31, 2015).

—. 2014a. "China Focus: China Trumpets 'Core Socialist Values' Amid Moral Decline.” February 17. http://news.xinhuanet.com/english/indepth/2014-02/17/c_ 133121953.htm (accessed February 22, 2015).

—. 2014b. Guoxue yu shehuizhuyi hexin jiazhiguan - minzhu 国学与社会主义核心价值观 一民主 [National learning and socialist core values - democracy]. August 15. http:// news.xinhuanet.com/edu/2014-08/15/c_1112089028_2.htm (accessed February 22, 2015).

Yang, Guobin. 2009. The Power of the Internet in China: Citizen Activism Online. New York: Columbia University Press.

Yang Henguun. 2014. "What Occupy Central Reveals about China." Diplomat, November 27.

Zhang Mingshu 张明澍. 1994. Zhongguo zhengzhiren: Zhongguo gongmin zhengzhi sushi diaocha baogao 中国政治人：中国公民政治素质调查报告 [Chinese political man: Survey report of Chinese political citizenship]. Beijing: Social Science Academy Press.

—. 2013. Zhongguoren xiangyao shenmeyang minzhu 中国人想要什么洋民主 [What kind of democracy do Chinese want?]. Beijing: Social Science Documents Press.

Zhaо, Yuezhi. 1998. Media, Market, and Democracy in China: Between the Party Line and the Bottom Line. Urbana: University of Illinois Press. 